\title{
SYNTHESIS AND ANTI-HIV ACTIVITY OF SOME NEW AMINOADAMANTANE HETEROCYCLES
}

\author{
G. Fytas ${ }^{a^{*}}$, G. Stamatiou ${ }^{a}$, G. B. Foscolos ${ }^{a}$, A. Kolocouris ${ }^{a}$, N. Kolocouris ${ }^{a}$, M. Witvrouw ${ }^{b}$, C. \\ Pannecouque $^{b}$ and E. De Clercq ${ }^{b}$. \\ ${ }^{a}$ Department of Pharmacy, Division of Pharmaceutical Chemistry, University of Athens, Panepistimioupoli- \\ Zografou GR-1577I Athens, Greece. \\ ${ }^{b}$ Rega Institute for Medical Research, Katholieke Universiteit Leuven, B-3000 Leuven, Belgium.
}

\begin{abstract}
A new class of aminoadamantane heterocycles has been synthesized and examined for anti-HIV activity. Three compounds proved to be active against the replication of HIV-1 in MT-4 cells with an EC 50 ranging from 3.6 to $75.2 \mu \mathrm{M}$. No activity was noted with any of the compounds against HIV-2.

() 1997 Elsevier Science Ltd.

In the past the interesting antiviral properties of adamantane derivatives have been demonstrated. ${ }^{1}$ During our program to explore new structure-antiviral activity relationships of aminoadamantanes ${ }^{2,3}$ we found that spiroheterocycles 1, 2 and diaminoderivative 3 exhibited borderline anti-HIV-1 activity (Figure 1). ${ }^{3}$
\end{abstract}

\section{Figure 1}

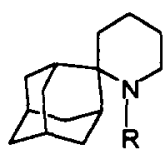

1

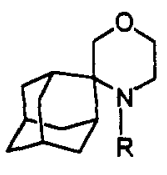

2

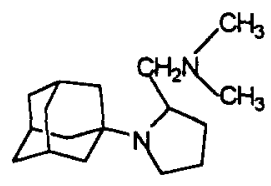

3

This observation prompted us to synthesize the novel 2-(1-adamantyl)piperidine heterocycles 7, 9a-d, 12a, b and 13a, b with relevant structural features as regards compounds 1,2 and 3 . In this new series, the piperidine is allowed to rotate freely with respect to the adamantane nucleus, while the nitrogen atom is substituted by an alkyl, dialkylaminoethyl or carbamoyl group.

The synthetic route followed for the preparation of the new compounds is illustrated in Scheme 1.

Tertiary alcohol 5 was synthesized from ester 4 and 1,4-bis(bromomagnesium)butane. ${ }^{4}$ The reaction of the tertiary alcohol 5 with conc. sulfuric acid and sodium azide led to the tetrahydropyridine $6,{ }^{5}$ the formation of which was accomplished by cyclopentane ring expansion of the intermediate alkylazide via nitrenium ion. ${ }^{6}$

\footnotetext{
•E-mail: akolokou@atlas.uoa.gr Fax: +301 - 7238297
} 


\section{Scheme 1}

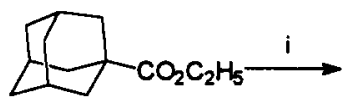

4

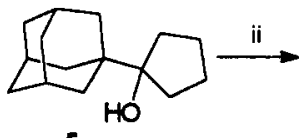

5<smiles>C1CCC(C23CC4CC(CC(C4)C2)C3)=NC1</smiles>

6 iii<smiles>C1CCC(C23CC4CC(CC(C4)C2)C3)NC1</smiles><smiles>CCC#N</smiles><smiles>[R]=C(C)C</smiles><smiles>[R]CN1CCCCC1C12CC3CC(CC(C3)C1)C2</smiles><smiles>CCNC1CCCCC1C12CC3CC(CC(C3)C1)C2</smiles>

viii for $13 a$ ix for 13b

8a-d

9a-d<smiles>O=C(O)N1CCCCC1C1(C(=O)Br)CC2CC3CC(C3)CC21</smiles><smiles>CC1C2CC3CC1CC(C1CCCCN1)(C3)C2</smiles><smiles>[Y]NC([Y])C</smiles>

13a,b

8a: $R=O E t, 9 a: R=H$

8b, 9b: $\mathrm{R}=\mathrm{CH}_{3}$

8c, 9c: R = cyclopropyl

8d, 9d: $\mathrm{R}=\mathrm{C}_{6} \mathrm{H}_{5}$<smiles>[R]NC(=O)NCCN1CCCCC1C12CC3CC(C1)CC(C14CC5CC(CC(C5)C1)C4)(C3)C2</smiles>

11a, 12a: $N_{V_{R}}^{\prime R}=N^{\prime} \backslash_{\mathrm{CH}_{3}}$

11b, 12b: $N_{R}^{R}=N$

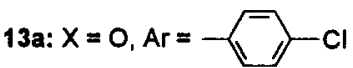

13b: $x=s, A r=$

Reagents: (i) $\mathrm{BrMg}\left(\mathrm{CH}_{2}\right)_{4} \mathrm{MgBr} / \mathrm{THF}$ and then $\mathrm{NH}_{4} \mathrm{Cl}, \mathrm{H}_{2} \mathrm{O}, 67 \%$; (ii) $\mathrm{NaN}_{3} / \mathrm{Conc}_{2} \mathrm{H}_{2} \mathrm{SO}_{4} / \mathrm{CHCl}_{3}$, $00 \mathrm{C}$, 1.5h, $73 \%$; (iii) $\mathrm{NaBH}_{4} / \mathrm{CH}_{3} \mathrm{OH}, 00 \mathrm{C}$, and then RT for $20 \mathrm{~h}, 92 \%$; (iv) RCOCl, $\mathrm{Et}_{3} \mathrm{~N}, \mathrm{Et}_{2} \mathrm{O}$ or THF, $00 \mathrm{C}$, and then RT for $24 \mathrm{~h}(66-91 \%) ;(\mathrm{V}) \mathrm{LiAlH} 4 \mathrm{THH}, 15 \mathrm{~h}$ reflux $(70-89 \%)$;

(vi) $\mathrm{BrCH}_{2} \mathrm{COCl} / \mathrm{K}_{2} \mathrm{CO}_{3} / \mathrm{CHCl}_{3} / \mathrm{H}_{2} \mathrm{O}, 00 \mathrm{C}$, and then $\mathrm{RT}$ for $2.5 \mathrm{~h}, 52 \%$; (vii) $\mathrm{R} 2 \mathrm{NH}$, benzene, $00 \mathrm{C}$, and then RT for $24 \mathrm{~h}$ (76-86\%); (viii) 4-chlorophenyl isocyanate, $\mathrm{Et}_{2} \mathrm{O}, 20 \mathrm{~min}$ reflux, $70 \%$;

(ix) 2,4-dichlorophenyl isothiocyanate, acetone, $10 \mathrm{~min}$ reflux, $53 \%$. 
Reduction of imine 6 with $\mathrm{NaBH}_{4}$ gave 2-(1-adamantyl)piperidine 7. The latter was suitably $\mathrm{N}$-acylated to afford the amides $8 \mathrm{a}-\mathrm{d}$ which were converted to the piperidines $9 \mathrm{a}-\mathrm{d}$ by reduction with $\mathrm{LiAlH}_{4}$. $\mathrm{N}$ bromoacetylation of the parent piperidine 7 resulted in bromoacetamide 10, which after treatment with the appropriate secondary amines gave the dialkylaminoacetamides $11 \mathrm{a}, \mathrm{b}$. These compounds were converted to the corresponding diamines $12 a$, $b$ by means of $\mathrm{LiAlH}_{4}$. The preparation of ureas $13 \mathbf{a}$, $\mathbf{b}$ was achieved by treatment of the piperidine 7 with the suitable isocyanate or isothiocyanate.

The new aminoadamantane heterocycles ${ }^{7} 7,9 a-d, 12 a, b$ and 13a, b were examined for activity against the replication of human immunodeficiency virus type 1 (HIV-1) and type 2 (HIV-2) (Table 1). Cytotoxicity of the compounds was monitored in parallel with anti-HIV activity. Both activity and cytotoxicity were determined by the MTT method. ${ }^{8}$

Table 1. Anti-HIV-1 and anti-HIV-2 activity and cytotoxicity of the new aminoadamantane heterocycles in MT-4 cells ${ }^{\text {a }}$

\begin{tabular}{|c|c|c|c|}
\hline \multirow[t]{2}{*}{ Compound } & \multicolumn{2}{|c|}{$\mathrm{EC}_{30}{ }^{\mathrm{b}}(\mu \mathrm{M})$} & \multirow[t]{2}{*}{$\mathrm{CC}_{50}{ }^{\mathrm{c}}(\mu \mathrm{M})$} \\
\hline & $\begin{array}{c}\text { HIV-1 } \\
\text { (IIIB/LAI) }\end{array}$ & $\begin{array}{l}\text { HIV-2 } \\
\text { (ROD) }\end{array}$ & \\
\hline 7 & $>403$ & $>403$ & 403 \\
\hline $9 \mathbf{a}$ & $>415$ & $>415$ & $413.2=$ \\
\hline $9 b$ & $>419$ & $>419$ & 417.4 \\
\hline $9 c$ & 75.2 & $>265$ & 263.0 \\
\hline 9d & $>64$ & $>64$ & 62.7 \\
\hline $12 \mathrm{a}$ & 40.8 & $>276$ & 274.5 \\
\hline $12 b$ & 3.6 & $>54$ & 52.6 \\
\hline $13 a$ & $>13$ & $>13$ & 12.6 \\
\hline $13 b$ & $>19$ & $>19$ & 17.7 \\
\hline \multicolumn{4}{|c|}{$\begin{array}{l}{ }^{\mathrm{a}} \mathrm{MT}-4 \text { represents a human } \mathrm{T}-4 \text { lymphocytic cell line. }{ }^{\mathrm{b}} 50 \% \\
\text { Effective concentration, or concentration required to protect } \mathrm{MT}-4 \\
\text { cells against the cytopathogenicity of HIV by } 50 \% \text {. }{ }^{\mathrm{c}} 50 \% \text { Cytotoxic } \\
\text { concentration, or concentration required to reduce the viability of } \\
\text { MT- } 4 \text { cells by } 50 \% \text {. All data represent mean values for at least two } \\
\text { separate experiments. }\end{array}$} \\
\hline
\end{tabular}

From the $\mathrm{EC}_{50}$ and $\mathrm{CC}_{50}$ values (Table 1 ) compounds $9 \mathrm{c}$ and 12a, $\mathbf{b}$ appeared to be active against $\mathrm{HIV}-1$ at non-toxic concentrations. Interestingly, no activity was noted with any of the compounds against HIV-2.

The unsubstituted, $N$-methyl, $N$-ethyl, and $\mathrm{N}$-benzyl derivatives $7,9 \mathbf{a}, \mathbf{b}, \mathbf{d}$, proved to be inactive against $\mathrm{HIV}$-1, whereas the $N$-cyclopropylmethyl derivative $9 \mathrm{c}$ showed an $\mathrm{EC}_{50}$ of $75.2 \mu \mathrm{M} . N$-substitution by a dialkylaminoethyl group further improved the activity. Indeed, compounds $12 \mathrm{a}$ and $12 \mathrm{~b}$ showed an $\mathrm{EC}_{50}$ of 
40.8 and $3.6 \mu \mathrm{M}$ respectively. Interestingly, replacement of the dimethylamino moiety in $12 \mathrm{a}$ by a piperidino, $\mathbf{1 2 b}$, led to a substantial increase in potency.

Aminoadamantane derivatives have not primarily been pursued as inhibitors of HIV replication. This fact makes the activity of 9c and 12a, b againt HIV-1 even more important. Analogous to the mechanism of antiinfluenza virus activity exhibited by adamantanamines, ${ }^{\prime}$ the new compounds may be postulated to interact with an early step (i.e. fusion/uncoating) of the HIV replicative cycle.

Since the presence of the second amino group through $N$-substitution of the parent heterocycle 7 enhances the anti-HIV-1 potency, studies are currently underway to obtain further insight in the structureactivity relationship of this series of compounds.

Acknowledgment: These investigations were partially supported by a research grant from the Ministry of Industry, Energy and Technology of Greece (Programme from the Promotion of Research Scientists), and by the Biomedical Research Programme of the European Commission.

\section{References and Notes}

1. (a) In Burger's Medicinal Chemistry; Wolff, M. E., Ed.; John Wiley \& Sons: New York, 1981; Part II, pp 557-560. (b) Hay, A. J. Semin. Virol. 1992, 3, 21.

2. Kolocouris, N.; Foscolos, G. B.; Kolocouris A.; Marakos, P.; Pouli, N.; Fytas, G.; Ikeda, S.; De Clercq, E. J. Med. Chem. 1994, 37, 2896.

3. Kolocouris, N.; Kolocouris A.; Foscolos G. B.; Fytas, G.; Neyts, J.; Padalko, E.; Balzarini, J.; Snoeck, R.; Andrei, G.; De Clercq, E. J. Med. Chem. 1996, 39, 3307.

4. Fytas, G.; Kolocouris, N.; Foscolos, G. B.; Vamvakides, A. Eur. J. Med. Chem. 1991, 26, 563.

5. The spectroscopic characteristics of 2-(1-adamantyl)-3,4,5,6-tetrahydropyridine 6 are as follows: IR (Nujol) $v(\mathrm{C}=\mathrm{N}) 1651 \mathrm{~cm}^{-1},{ }^{1} \mathrm{H} \mathrm{NMR}\left(\mathrm{CDCl}_{3}, 200 \mathrm{MHz}\right) \delta$ 1.44-1.70 (m, 16H, 2,4,6,8,9-adamantane H, 4,5piperidine $\mathrm{H}$ ), $1.96(\mathrm{~s}, 3 \mathrm{H}, 3,5,7$-adamantane $\mathrm{H}), 2.06-2.12(\mathrm{t}, 2 \mathrm{H}, 3$-piperidine $\mathrm{H}), 3.50-3.60(\mathrm{~m}, 2 \mathrm{H}, 6$ piperidine $\mathrm{H}$ ); ${ }^{13} \mathrm{C}$ NMR $\left(\mathrm{CDCl}_{3}, 50 \mathrm{MHz}\right) \delta 19.6$ (4-piperidine $\mathrm{C}$ ), 21.9 (5-piperidine $\mathrm{C}$ ), 23.5 (3-piperidine C), 28.4 (3,5,7-adamantane C), 36.8 (4,6,10-adamantane C), 39.6 (2,8,9-adamantane C), 41.3 (1adamantane C), 49.1 (6-piperidine C), 177.0 (2-piperidine C).

6. Astier, A.; Plat, M. Tetrahedron Lett. 1978, 2051.

7. Satisfactory analytical results were obtained for all new compounds. The spectral properties were in accord with the assigned structures.

8. Pauwels, R.; Balzarini, J.; Baba, M.; Snoeck, R.; Schols, D.; Herdewyn, P.; Desmyter, J.; De Clercq, E. J. Virol. Methods 1988, 20, 309. 